BogumiŁa Maria BobIK

University of Silesia, Poland, Katowice

DOI: $10.13166 / \mathrm{JMS} / 125596$

bogumilabobik@gmail.com

ORCID iD: https://orcid.org/0000-0001-7548-858X

\title{
THE IMPORTANCE OF INTERPERSONAL SKILLS IN THE WORK OF A SCHOOL COUNSELLOR
}

\section{ZNACZENIE UMIEJĘTNOŚCI INTERPERSONALNYCH W PRACY PEDAGOGA SZKOLNEGO}

\begin{abstract}
The main aim of the study was to diagnose interpersonal skills of professionally active school counselors. The research was of diagnostic and descriptive nature. Interpersonal Competence Questionnaire (ICQ-R), compiled by Waldemar Klinkosz, Justyna Iskra and Magdalena Dawidowicz, was used to collect the research material. A diagnosis of five dimensions of interpersonal competences of counsellors, necessary for effective functioning in interpersonal relations was made. They were: initiating relationships, assertive interactions, self-disclosure, and emotional support. The analysis of research results indicates that the surveyed counsellors are people who are able to initiate relationships, meet people and conduct conversations with them. In relations with others, they are focused on providing emotional support and self-disclosure; they are able to express their opinions and positions. They deal well with the problems and conflicts that they have to solve in the educational environment. They can emphasize their position on important matters, and enforce their rights and clearly express expectations. Their interpersonal skills predispose them to perform the tasks of a school counsellor.

KEYWORDS: emotional support, self-disclosure, school counsellor, interpersonal skills, relationship initiation, assertive impacts.

SŁOWA KLUCzowe: pedagog szkolny, umiejętności interpersonalne, inicjowanie relacji, asertywne oddzialywania, ujawnianie siebie, emocjonalne wspieranie.
\end{abstract}




\section{WPROWADZENIE}

Umiejętności interpersonalne wynikają z naturalnej skłonności człowieka do wchodzenia $\mathrm{w}$ relacje $\mathrm{z}$ innymi osobami i angażowania się $\mathrm{w}$ życie społeczne. Inni ludzie są niezbędni każdemu z nas do ujawniania i realizowania posiadanych możliwości, umiejętności, potrzeb i dążeń. Jako istoty społeczne „W zasadzie wszystko co czynimy, robimy we współpracy z innymi, pracując dla innych ludzi lub przynajmniej licząc się z ich zdaniem. Nasze zachowania mają naturę interpersonalną, nawet wtedy, gdy nie dochodzi do bezpośrednich interakcji z innymi” (Smółka, 2016, s. 26). Głównymi motywami ludzkiego działania w zakresie zachowań społecznych są bowiem dwie potrzeby: aprobaty oraz władzy (statusu). Potrzeba aprobaty budzi pragnienia przynależności do grupy, która może zapewnić uznanie i akceptację, podczas gdy potrzeba władzy ujawnia pragnienie kierowania własnym życiem oraz wpływania na otoczenie (Klinkosz, Iskra, Dawidowicz, 2017, s. 11).

W odniesieniu do profesji społecznych, a taką jest zawód pedagoga szkolnego, umiejętności interpersonalne odgrywają kluczową rolę w wypełnianiu codziennych obowiązków służbowych.

Artykuł przedstawia przegląd definicji i modeli kompetencji społecznych na podstawie kwerendy dostępnej literatury oraz wyników badań własnych tego obszaru zasobów osobowych pedagogów szkolnych.

\section{TEORETYCZNA ANALIZA KOMPETENCJI SPOÆECZNYCH}

Termin kompetencji społecznych wprowadził na grunt psychologii Robert W. White. Zdefiniował je jako „każdą umiejętność człowieka przyczyniającą się do skutecznej interakcji z otoczeniem” (Oleś, 1998, s. 23; Sęk, 2004, s. 74-75). W ten sposób podkreślał znaczenie plastyczności w zachowaniach społecznych, pozwalające danej osobie osiągnąć zamierzone cele, nie niszcząc jednocześnie relacji z innymi ludźmi. Z kolei Krystyna Skarżyńska ujęła kompetencje społeczne jako umiejętności osiągania celów społecznych i jednostkowych z jednoczesnym zachowaniem dobrych stosunków z partnerami interakcji (Skarżyńska, 1981, s. 48-56). W psychologii pojęcie to często jest utożsamiane $z$ inteligencją społeczną, inteligencją emocjonalną, społecznymi zdolnościami do wykonywania określonych czynności czy też z umiejętnościami społecznymi. 
Katarzyna Martowska podkreśliła, że w literaturze wciąż pojawiają się nowe ujęcia kompetencji społecznych, zróżnicowane ze względu na przyjęte założenia teoretyczne oraz sposoby pomiaru zmiennych. Kompetencje społeczne są określane za pomocą takich terminów, jak na przykład: kompetencja (efektywność) komunikacyjna, kompetencja relacyjna, kompetencja do efektywnego działania, zdolności społeczne, komunikacyjne, umiejętność adaptacji (Martowska, 2012, s. 15).

Mówiąc o definiowaniu kompetencji społecznych, należy zwrócić uwagę na to, że wyróżnia się dwa rodzaje podejść. Pierwsze - akcentujące zachowania pożądane społecznie, czyli takie, które służą rozwiązywaniu konfliktów i byciu akceptowanym przez innych. Drugie - służące osiągnięciu własnych celów i korzyści w sytuacjach społecznych (Berk, 1996, za: Klinkosz, Iskra, Dawidowicz, 2017, s. 12).

W pojmowaniu kompetencji społecznych zauważa się, że pozwalają one osiągać określone cele osobiste i społeczne, które różnią się u poszczególnych osób. Reprezentantem takiego ujęcia jest Michael Argyle, który definiuje kompetencje społeczne jako „zdolności, posiadanie niezbędnych umiejętności do tego, aby wywrzeć pożądany wpływ na innych ludzi w sytuacjach społecznych" Argyle, 1999, s. 133). Ludzie społecznie kompetentni potrafią oddziaływać na innych, przekonywać innych do własnego pomysłu i sposobu jego realizacji, poddania się konkretnej terapii (Smółka, 2008, s. 45-54).

$\mathrm{Na}$ istotę społecznego zaangażowania przy określaniu kompetencji społecznych zwróciła uwagę Urszula Jakubowska, tym samym wpisała się do grupy naukowców określających je jako zdolność do uczestniczenia w relacjach interpersonalnych. W komunikacyjnym ujęciu kompetencji społecznych wyróżniła dwie grupy zdolności. Pierwszą, zwaną zdolnościami specyficznymi tworzą trzy elementy: akceptacja różnorodności „ja” publicznego, wrażliwość retoryczna oraz uważność.

Drugą, nazywaną umiejętnościami komunikacyjnymi, tworzą: trafna interpretacja partnera interakcji, aktywne słuchanie, zgodność zachowań komunikacyjnych z kontekstem społecznym, plastyczność strategii komunikacyjnych, modulowanie zachowań niewerbalnych (Jakubowska 1998, s. 29-40). 
Kompetencje społeczne bywają także wyjaśniane poprzez przywołanie określonych sposobów zachowania, jak: pewność siebie, mówienie „nie”, wyrażanie życzeń, żądań, podtrzymywanie rozmowy, wczuwanie się, granie roli, konformizm, wyrażanie siebie (Klinkosz, Iskra, Dawidowicz, 2017, s. 13-14).

Najbardziej popularny model kompetencji społecznych opisał M. Argyle. Autor przyjmuje, że na kompetencje społeczne składają się różne umiejętności, do których zalicza: umiejętności odbierania i przekazywania informacji (werbalnych, niewerbalnych), udzielania gratyfikacji i wsparcia, współodczuwania i rozumienia punktu widzenia innych, rozwiązywania problemów, prezentowania siebie, bycia asertywnym (Argyle, 1998, s. 77-104).

Do modelu M. Argyle nawiązuje Anna Matczak. Autorka uważa, że przez kompetencje społeczne należy rozumieć „złożone umiejętności warunkujące efektywność radzenia sobie w określonego typu sytuacjach społecznych, nabywane przez jednostkę w toku treningu społecznego" (Matczak, 2012, s. 7). Zatem odnoszą się one do efektywności w sytuacjach społecznych, a wskaźnikami efektywności są: osiąganie przez jednostkę własnych celów z jednej strony, z drugiej zaś zgodność z oczekiwaniami otoczenia społecznego. Zatem rodzi się pytanie, jakie elementy wchodzą w skład kompetencji społecznych? Jan Borkowski wymienia następujące ich elementy:

- wiedza społeczna, czyli systematyczne uczenie i dokształcanie,

- wiedza o sobie samym,

- społeczne doświadczenie jako suma doświadczeń życiowych (rodzina, przyjaciele, znajomi, praca),

- wiedza o zasadach funkcjonowania małych grup społecznych oraz dużych zbiorowości ludzkich,

- osobowość społeczna jako zdolność do odczytywania, rozumienia własnych stanów emocjonalnych oraz stanów emocjonalnych innych ludzi, nazywana również inteligencją emocjonalną,

- inteligencja społeczna to umiejętność rozwiązywania konfliktów oraz próba współpracy i współżycia z innymi,

- dojrzałość moralna,

- autorytet społeczny,

- inne zdolności i umiejętności (Borkowska, 2003, s. 117). 
Przedstawiona krótka analiza podejść do ujmowania i definiowania kompetencji społecznych pozwala zauważyć, że stanowią one podstawowy warunek radzenia sobie w sytuacjach interpersonalnych. Decydują o efektywności w nawiązywaniu oraz podtrzymywaniu kontaktów z innymi osobami. Ich przejawem są: „inicjatywa, rozumienie stanów emocjonalnych innych ludzi, zdolność do pracy w zespole umiejętności rozwiązywania konfliktów” (Klinkosz, Iskra, Dawidowicz, 2017, s. 15). Z przedstawionych definicji wynika też, że odnoszą się one do:

- posiadanej wiedzy, która w ujęciu pedagogicznym oznacza treści utrwalone w umyśle ludzkim w wyniku gromadzenia doświadczeń oraz uczenia się; zatem wiedza to ogół wiadomości zdobytych dzięki uczeniu się, zasób wiadomości z jakiejś dziedziny, co wiąże się z funkcjonowaniem poznawczym człowieka (Okoń, 1998, s. 117),

- posiadanych umiejętności, czyli „gotowości i możliwości celowego działania $\mathrm{z}$ wyborem i zastosowaniem najbardziej odpowiednich wyborów wraz z uwzględnieniem określonych warunków, gwarantujących właściwe rezultaty tego działania, to sprawdzona możliwość celowego wykonania pewnego określonego rodzaju działań”, co wiąże się z behawioralnym funkcjonowaniem człowieka,

- postaw, czyli umiejętności przeprowadzania określonego działania poprzez własną postawę zachowania, co można połączyć z motywacyjno-emocjonalnym funkcjonowaniem człowieka (Smółka, 2008, s. 35).

W niniejszym opracowaniu, analizując kompetencje interpersonalne pedagogów szkolnych, przyjęto za Duanem Buhmesterem i współpracownikami, że stanowią one „szczególny aspekt kompetencji społecznych warunkujących efektywne radzenie sobie w różnego typu sytuacjach międzyludzkich" (Klinkosz, Iskra, Dawidowicz, 2017, s. 30). Do najważniejszych wyznaczników kompetencji interpersonalnych należą:

- skuteczność radzenia sobie z konkretnymi wyzwaniami interpersonalnymi oraz umiejętność podejmowania adekwatnych działań w danej sytuacji,

- zakres wyzwań interpersonalnych, w których dana osoba potrafi być skuteczna, 
- satysfakcja z posiadanych kontaktów i relacji interpersonalnych oraz własnego wizerunku społecznego (Smółka, 2016, s. 35).

Wymienione wyznaczniki pozwalają stwierdzić, że kompetencje interpersonalne warunkują relacje $\mathrm{z}$ innymi osobami. Ich nawiązywanie i podtrzymywanie wymaga elementarnych umiejętności, posiadanych na ogół przez przedstawicieli profesji społecznych, wśród których można wymienić pedagoga szkolnego. Do tych umiejętności M. Argyle zalicza:

- empatię - umiejętność podejmowania różnych ról społecznych istotnych z punktu widzenia współpracy zachodzącej pomiędzy jednostkami oraz układania pozytywnych relacji z innymi podmiotami,

- nagradzanie - umiejętność motywowania innych do współpracy oraz przekazywania wzmocnień społecznych z innym podmiotom,

- asertywność - umiejętność obrony własnych poglądów bez okazywania agresji,

- rozumienie kontekstu społecznego - umiejętność rozwiązywania konfliktów,

- komunikację werbalną i niewerbalną,

- umiejętność własnej autoprezentacji (Argyle 2002, s. 107-142).

Zakłada się, że dla efektywnego funkcjonowania pedagoga szkolnego $\mathrm{w}$ relacjach międzyosobowych duże znaczenie ma pięć wymiarów kompetencji interpersonalnych, a mianowicie:

1) inicjowanie relacji - rozpoczynanie interakcji i relacji interpersonalnych;

2) asertywne oddziaływanie - deklarowanie osobistych praw i asertywnego niezadowolenia, wyrażanie krytyki z działań innych;

3) ujawnianie siebie - dzielenie się osobistymi informacjami na swój temat;

4) emocjonalne wspieranie - udzielanie emocjonalnego wsparcia innym;

5) rozwiązywanie konfliktów - konstruktywne rozwiązywanie konfliktów interpersonalnych bez kłótni i krytyki. Wymienione wymiary kompetencji interpersonalnych będą stanowiły przedmiot analizy badawczej. 


\section{ZAŁó̇eniA MetodologiczNe}

Kompetencje społeczne to naturalna skłonność człowieka do wchodzenia $\mathrm{w}$ relacje $\mathrm{z}$ innymi osobami i angażowanie się w życie społeczne. W artykule przyjmuje się, że „kompetencje interpersonalne stanowią szczególny aspekt kompetencji społecznych, czyli złożonych umiejętności warunkujących efektywne radzenie sobie w różnego typu sytuacjach międzyludzkich" (Klinkosz, Iskra, Dawidowicz, 2017, s. 30). Jest ona zróżnicowana ze względu na przyjęte założenia teoretyczne oraz sposoby pomiaru zmiennych.

Populacją docelową badania była grupa zawodowa pedagogów szkolnych, zatrudniona w różnych typach szkół, którą można zdefiniować następująco:

- podmiot: pedagodzy szkolni - grupa 212 osób,

- jednostka próby: wybrane szkoły podstawowe, zespoły szkół, szkoły ponadpodstawowe branżowe i ogólnokształcące,

- zakres przestrzenny: województwo śląskie, opolskie i małopolskie,

- czas i miejsce badań: rok 2018 (Matuszak, 2011, s. 33-39).

W toku postępowania badawczego podjęto próbę odpowiedzi na następujące pytania badawcze:

- jak kształtują umiejętności społeczne badanych pedagogów szkolnych?

- jakie znaczenie dla wykonywania obowiązków zawodowych mają wybrane wymiary umiejętności interpersonalnych, jak: inicjowanie relacji, asertywne oddziaływanie, ujawnianie siebie, emocjonalne wspieranie, rozwiązywanie konfliktów?

- w jaki sposób umiejętności społeczne kształtują styl pracy pedagoga szkolnego?

Do badania kompetencji interpersonalnej pedagogów szkolnych wykorzystano Kwestionariusz kompetencji interpersonalnych (ICQ-R), skonstruowany w Stanach Zjednoczonych w latach siedemdziesiątych ubiegłego wieku. Autorami są Duane Burhmester z Uniwersytetu Kalifornijskiego, Wyndol Furman z Uniwersytetu w Denver oraz Mitchel T. Wittenberg i Harry T. Reis z Uniwersytetu w Rochester. Polska adaptacja kwestionariusza została opracowana w 2015 roku w Katedrze Psychologii Społecznej i Psychologii Religii KUL przez Magdalenę Dawidowicz, Waldemara Klinkosza i Jacka Śliwaka 
(Dawidowicz, Klinkosz, Śliwak, 2015). Kwestionariusz ICQ-R bada pięć wymiarów kompetencji interpersonalnych, nieodzownych do efektywnego funkcjonowania w relacjach międzyosobowych. Należą do nich:

- inicjowanie relacji (IR) - rozpoczynanie interakcji i relacji interpersonalnych,

- asertywne oddziaływanie (AO) - deklarowanie osobistych praw i asertywnego niezadowolenia, wyrażanie krytyki z działań innych ludzi,

- ujawnianie siebie (US) - dzielenie się osobistymi informacjami na swój temat,

- emocjonalne wspieranie (EW) - udzielanie emocjonalnego wsparcia innym osobom,

- rozwiązywanie konfliktów (RK) - konstruktywne rozwiązywanie konfliktów interpersonalnych, bez kłótni i krytyki.

Badani pedagodzy dla każdego z wymiarów uzyskiwali punkty, które po zsumowaniu dawały wynik surowy dla danego rodzaju kompetencji interpersonalnej zgodnie z przynależnością itemów do poszczególnych skal. Wyniki znormalizowane podano w skali tenowej, dla której średnia wynosi 50T, odchylenie standardowe 10T. Przedział 40-60T odpowiada wynikom przeciętnym (średnim), wynik poniżej 40T uznaje się za znacząco niższy, powyżej $60 \mathrm{~T}$ zaś za znacząco podwyższony. Ze względu na mały, niereprezentatywny udział mężczyzn w badaniu (6,6\%) zrezygnowano z podziału norm tenowych na kobiety i mężczyzn. Poniżej zaprezentowano tabelaryczne ujęcie i interpretację uzyskanych wyników.

\section{WYNIKI BADAŃ}

Uzyskane wyniki uporządkowano i opisano zgodnie z wyróżnionymi wymiarami kompetencji interpersonalnych. Uzyskane dane stały się podstawą do sformułowania wniosków końcowych.

\section{Inicjowanie relacji (IR)}

Skala bada umiejętność rozpoczynania interakcji i relacji interpersonalnych zarówno z osobą znaną, jak i nieznaną. IR określa aspekt angażowania się w społeczne interakcje, zdolność do tworzenia i modyfikowania zacho- 
wań, które ułatwiają trwanie w relacjach społecznych oraz efektywność nawiązywania tych relacji. Wyniki uzyskane w tej skali ujęto w tabelach 1 i 2.

Tabela 1.

Wyniki uzyskane przez pedagogów w zakresie skali Inicjowanie relacji (IR)

\begin{tabular}{|c|c|c|c|}
\hline Wynik surowy & $\begin{array}{c}\text { Wynik przeliczony } \\
\text { w tenach (T) }\end{array}$ & Liczba & $\%$ \\
\hline 12 & 30 & 1 & 0,5 \\
\hline $17-18$ & 36,37 & 3 & 1,4 \\
\hline $19-20$ & 38,40 & 2 & 0,9 \\
\hline $21-22$ & 41,42 & 8 & 3,8 \\
\hline $23-24$ & 43,45 & 19 & 9,0 \\
\hline $25-26$ & 46,48 & 26 & 12,3 \\
\hline $27-28$ & 50,51 & 24 & 11,2 \\
\hline $29-30$ & 53.55 & 32 & 15,1 \\
\hline $31-32$ & 56,58 & 45 & 21,2 \\
\hline $33-34$ & 60,62 & 22 & 10,4 \\
\hline $35-36$ & 64,65 & 12 & 5,7 \\
\hline $37-38$ & 68,70 & 8 & 3,8 \\
\hline $39-40$ & 73,78 & 10 & 4,7 \\
\hline suma & & 212 & 100,0 \\
\hline
\end{tabular}

Źródło: opracowanie własne.

Tabela 2.

Wyniki uzyskane przez pedagogów w zakresie skali IR ujęte w przedziałach tenowych

\begin{tabular}{|c|c|c|}
\hline Wynik & Liczba & $\%$ \\
\hline niski & 6 & 2,8 \\
\hline przeciętny & 154 & 72,6 \\
\hline wysoki & 52 & 24,6 \\
\hline suma & 212 & 100,0 \\
\hline
\end{tabular}

Źródło: opracowanie własne. 
Przedstawione dane pokazują, że większość badanych pedagogów w zakresie skali Inicjowanie relacji uzyskała wynik przeciętny (72,6\%). Dość liczna była też grupa $\mathrm{z}$ wynikiem wysokim $(24,6 \%)$, a bardzo mała $\mathrm{z}$ wynikiem niskim (2,8\%). Biorąc pod uwagę wynik surowy, minimalną liczbą uzyskanych punktów było 12, maksymalną 40. Najliczniejsza grupa pedagogów osiągnęła wynik pomiędzy 26 a 32 punktami. Wartość środkowa wyniosła 30 punktów, co w skali tenowej wynosi 55 i jest wynikiem przeciętnym. Taki wynik wskazuje na znaczne zaangażowanie badanych w społeczne interakcje, umiejętność tworzenia i modyfikowania zachowań, które ułatwiają nawiązywanie i efektywne podtrzymywanie relacji międzyludzkich, w tym również przyjacielskich. Wskazuje także na popularność towarzyską i bycie lubianym przez innych. Ponadto posiadanie umiejętności inicjowania kontaktów międzyosobowych ułatwia przystosowanie do istniejących warunków społecznych i nowych sytuacji. Wiąże się ze społeczną ekspresyjnością i kontrolą oraz umiejętnościami, które pociągają za sobą zachowania typowe dla pedagogów, jak wypowiadanie się na temat sytuacji społecznych i gotowość do przyjmowania ról społecznych związanych z kierowaniem i przewodzeniem w różnych sytuacjach. Dobrze, kiedy wiąże się ze zdolnością do asertywnego oddziaływania.

\section{Asertywne oddzialywanie (AO)}

Asertywne oddziaływanie odnosi się do deklarowania osobistych praw, wypowiadania niezadowolenia w sposób asertywny i wyrażania krytyki działań innych ludzi. Skala bada zdolność do potwierdzania osobistych przywilejów i umiejętności wyrażania niezadowolenia $z$ ingerowania innych osób w sprawy jednostki. Ponadto przez AO należy rozumieć pewność siebie i wypowiadanie zdecydowanego „nie”. Z punktu widzenia zadań realizowanych przez pedagogów wydaje się to niezbędną umiejętnością. Zebrane dane ujęto w tabelach 3 i 4 . 
Tabela 3.

Wyniki uzyskane przez pedagogów w zakresie skali Asertywne oddziaływanie (AO)

\begin{tabular}{|c|c|c|c|}
\hline Wynik surowy & $\begin{array}{l}\text { Wynik przeliczony } \\
\text { w tenach }(\mathrm{T})\end{array}$ & Liczba & $\%$ \\
\hline 23 & 38 & 3 & 1,4 \\
\hline 24 & 40 & 5 & 2,4 \\
\hline 25 & 42 & 6 & 2,8 \\
\hline 26 & 44 & 10 & 4,7 \\
\hline 27 & 46 & 10 & 4,7 \\
\hline 28 & 48 & 17 & 8,0 \\
\hline 29 & 50 & 15 & 7,1 \\
\hline 30 & 52 & 17 & 8,0 \\
\hline 31 & 54 & 29 & 13,7 \\
\hline 32 & 56 & 32 & 15,2 \\
\hline 33 & 59 & 20 & 9,4 \\
\hline 34 & 61 & 17 & 8,0 \\
\hline 35 & 63 & 9 & 4,2 \\
\hline 36 & 66 & 5 & 2,4 \\
\hline 37 & 68 & 3 & 1,4 \\
\hline 38 & 70 & 4 & 1,9 \\
\hline 39 & 73 & 4 & 1,9 \\
\hline 40 & 79 & 6 & 2,8 \\
\hline suma & & 212 & 100,0 \\
\hline
\end{tabular}

Źródło: opracowanie własne.

Tabela 4.

Wyniki uzyskane przez pedagogów w zakresie skali AO ujęte w przedziałach tenowych

\begin{tabular}{|c|c|c|}
\hline Wynik & Liczba & $\%$ \\
\hline niski & 3 & 1,4 \\
\hline przeciętny & 161 & 76,0 \\
\hline wysoki & 48 & 22,6 \\
\hline suma & 212 & 100,0 \\
\hline
\end{tabular}

Źródło: opracowanie własne. 
Badani pedagodzy w większości (76\%) reprezentują przeciętny poziom asertywnego oddziaływania. Prawie co piąty pedagog ujawnia znacząco wysoki poziom tej umiejętności. Tylko nieliczni $(1,4 \%)$ uzyskali wynik niski, choć i w tym wypadku zbliża się on do przeciętnego, ponieważ wynosi 30T (tabela 58). Analiza wyników surowych pozwala stwierdzić, że minimalną liczbą punktów uzyskanych przez pedagogów było 23, maksymalną 40. Największa liczba pedagogów osiągnęła wynik surowy pomiędzy 29 a 33 punktami, natomiast wynik przeciętny wyniósł 31 punktów.

Uzyskane wyniki pozwalają stwierdzić, że badani pedagodzy posiadają umiejętność asertywnego oddziaływania w sytuacjach społecznych na poziomie pozwalającym im z odpowiednią pewnością siebie bronić własnych praw, wypowiadać niezadowolenie w sposób asertywny oraz dokonywać uzasadnionej krytyki działań innych ludzi. Są to osoby potrafiące mówić zdecydowane „nie”, prezentować własne życzenia oraz negatywne i pozytywne żądania. Są to też osoby, które na ogół potrafią troszczyć się o siebie i zapewniać sobie pomoc w sytuacjach trudnych, a także skutecznie realizować własne potrzeby i cele poprzez wywieranie wpływu na innych lub nieuleganie naciskom.

\section{Ujawnienie siebie (US)}

Skala Ujawnianie siebie odnosi się do dzielenia się osobistymi informacjami na swój temat. Pozwala ocenić skłonność do ujawniania osobistych spraw, a także zdradzania prywatnych sekretów. Michael Argyle $(1991,1998)$ uważa, że kompetencje w ujawnianiu siebie są niezbędne w sytuacjach trudnych, w których zaangażowana osoba pozostaje w bliskim kontakcie interpersonalnym $z$ innymi. Kompetencja ta warunkuje utrzymanie właściwych, stabilnych i szczerych relacji międzyosobowych oraz budowanie więzi. Jej posiadanie na odpowiednim poziomie jest więc ważne w wypełnianiu obowiązków zawodowych przez pedagogów szkolnych. Poniżej przedstawiono wyniki badań nad kompetencją US. 
Tabela 5.

Wyniki uzyskane przez pedagogów w zakresie skali Ujawnienie siebie (US)

\begin{tabular}{|c|c|c|c|}
\hline Wynik surowy & $\begin{array}{c}\text { Wynik przeliczony } \\
\text { w tenach (T) }\end{array}$ & Liczba & $\%$ \\
\hline 9 & 23 & 1 & 0,5 \\
\hline 12 & 30 & 2 & 0,9 \\
\hline $13-14$ & 32,34 & 7 & 3,3 \\
\hline $15-16$ & 35,37 & 9 & 4,2 \\
\hline $17-18$ & 39,40 & 14 & 6,6 \\
\hline $19-20$ & 42,44 & 15 & 7,2 \\
\hline $21-22$ & 46,47 & 25 & 11,8 \\
\hline $23-24$ & 49,51 & 25 & 11,8 \\
\hline $25-26$ & 52,54 & 33 & 15,6 \\
\hline $27-28$ & 56,57 & 34 & 16,0 \\
\hline $29-30$ & 59,61 & 19 & 9,0 \\
\hline $31-32$ & 62,64 & 12 & 5,7 \\
\hline $33-34$ & 66,68 & 9 & 4,2 \\
\hline $35-36$ & 70,72 & 2 & 0,9 \\
\hline $37-38$ & 75,79 & 2 & 0.9 \\
\hline $39-40$ & 82,85 & 3 & 1,4 \\
\hline suma & & 212 & 100,0 \\
\hline
\end{tabular}

Źródło: opracowanie własne

Tabela 6.

Wyniki uzyskane przez pedagogów w zakresie skali US ujęte w przedziałach tenowych

\begin{tabular}{|c|c|c|}
\hline Wynik & Liczba & $\%$ \\
\hline niski & 33 & 15,5 \\
\hline przeciętny & 151 & 71,4 \\
\hline wysoki & 28 & 13,1 \\
\hline suma & 212 & 100,0 \\
\hline
\end{tabular}

Źródło: opracowanie własne 
Zebrane wyniki (ujęte w tabelach 5 i 6) pozwalają stwierdzić, że większość pedagogów uzyskała w skali Ujawnianie siebie wynik przeciętny $(71,4 \%)$. Wyniki wysoki $(13,1 \%)$ oraz niski $(15,5 \%)$ są na zbliżonym poziomie i dotyczą zdecydowanej mniejszości badanych. Minimalny wynik surowy wyniósł 9 punktów, maksymalny 40 . Większość badanych uzyskała wynik surowy w granicach 21-28 punktów, wartość środkowa wyniosła 25.

Uzyskane wyniki wskazują na to, że zdecydowana większość badanych pedagogów szkolnych ma predyspozycje do budowania właściwych, silnych relacji z uczniem, rodzicem i współpracownikami. Są one podstawą rzeczywistej więzi, opartej na zaufaniu i szczerości. Doniosłe znaczenie ma tutaj posiadana przez pedagogów umiejętność porozumiewania się za pomocą kanału werbalnego i niewerbalnego, zgodnie z regułą dobrej komunikacji.

\section{Emocjonalne wspieranie (EW)}

Skala Emocjonalne wspieranie umożliwia ocenę zdolności emocjonalnego wspierania innych osób pozostających w bliskiej relacji. W przypadku pedagogów najistotniejsza jest zdolność udzielania wsparcia uczniom, ich rodzicom oraz nauczycielom i wychowawcom.

Wyniki skali ujęto w tabelach 7 i 8.

Na podstawie zebranych danych (tabele 7,8 ) można stwierdzić, że prawie wszyscy badani pedagodzy posiadają przeciętny $(72,2 \%)$ oraz wysoki $(26,0 \%)$ poziom umiejętności udzielania emocjonalnego wsparcia. Wśród badanych zaledwie 4 osoby $(1,8 \%)$ osiągnęły wynik niski; należy jednak podkreślić, że zbliżał się on do przeciętnego, bo wyniósł 35 i 39T (40T stanowi już wynik średni). Minimalna liczba punktów uzyskanych przez pedagogów wyniosła 24, maksymalna 40, wynik przeciętny to 33 punkty. Najliczniejszą grupę stanowili badani w przedziale pomiędzy 31 a 35 punktami.

Tak wysokie wyniki wskazują na to, że badani pedagodzy w szerokim zakresie udzielają innym emocjonalnego wsparcia $\mathrm{w}$ ramach prowadzonych przez siebie działań pomocowych. Potrafią także trafnie ocenić swoje umiejętności i powiązać z pozostałymi, jak inicjowanie relacji, asertywne oddziaływanie i ujawnianie siebie, dzięki czemu ich działania są planowe, ukierunkowane na realizację celu, $\mathrm{z}$ wyraźnie zaznaczonym przywództwem i poszanowaniem godności podopiecznego. 
Tabela 7.

Wyniki uzyskane przez pedagogów w zakresie skali Emocjonalne wspieranie (EW)

\begin{tabular}{|c|c|c|c|}
\hline Wynik surowy & $\begin{array}{c}\text { Wynik przeliczony } \\
\text { w tenach (T) }\end{array}$ & Liczba & $\%$ \\
\hline 24 & 35 & 2 & 0,9 \\
\hline 25 & 37 & 0 & 0,0 \\
\hline 26 & 39 & 2 & 0,9 \\
\hline 27 & 41 & 4 & 1,9 \\
\hline 28 & 43 & 6 & 2,9 \\
\hline 29 & 45 & 8 & 3,8 \\
\hline 30 & 48 & 14 & 6,6 \\
\hline 31 & 50 & 19 & 9,0 \\
\hline 32 & 53 & 46 & 21,6 \\
\hline 33 & 55 & 28 & 13,2 \\
\hline 34 & 58 & 28 & 13,2 \\
\hline 35 & 61 & 15 & 7,1 \\
\hline 36 & 63 & 10 & 4,7 \\
\hline 37 & 66 & 5 & 2,4 \\
\hline 38 & 68 & 5 & 2,4 \\
\hline 39 & 71 & 7 & 3,3 \\
\hline 40 & 77 & 13 & 6,1 \\
\hline suma & & 212 & 100,0 \\
\hline
\end{tabular}

Źródło: opracowanie własne.

Tabela 8.

Wyniki uzyskane przez pedagogów w zakresie skali EW ujęte w przedziałach tenowych

\begin{tabular}{|c|c|c|}
\hline Wynik & Liczba & $\%$ \\
\hline niski & 4 & 1,8 \\
\hline przeciętny & 153 & 72,2 \\
\hline wysoki & 55 & 26,0 \\
\hline suma & 212 & 100,0 \\
\hline
\end{tabular}

Źródło: opracowanie własne. 


\section{Rozwiązywanie konfliktów (RK)}

Rozwiązywanie konfliktów (RK) to konstruktywne radzenie sobie w sytuacjach konfliktów interpersonalnych, bez kłótni i krytyki. Skala ta pozwala ocenić tę umiejętność w odniesieniu do bliskich relacji zachodzących w rodzinie czy miejscu pracy. Wiąże się z miarą zadowolenia z tych relacji. Rozwiązywanie konfliktów stanowi istotny obszar działań pedagoga szkolnego, stąd też diagnoza tego obszaru pozwoli dopełnić charakterystykę ich kompetencji interpersonalnych. Poniżej przedstawiono wyniki uzyskane podczas badania.

Tabela 9.

Wyniki uzyskane przez pedagogów w zakresie skali Rozwiązywanie konfliktów (RK)

\begin{tabular}{|c|c|c|c|}
\hline Wynik surowy & $\begin{array}{l}\text { Wynik przeliczony } \\
\text { w tenach }\end{array}$ & Liczba & $\%$ \\
\hline 22 & 39 & 1 & 0,5 \\
\hline 24 & 42 & 4 & 1,9 \\
\hline 25 & 45 & 2 & 0,9 \\
\hline 26 & 47 & 7 & 3,3 \\
\hline 27 & 49 & 4 & 1,9 \\
\hline 28 & 51 & 10 & 4,7 \\
\hline 29 & 53 & 17 & 8,0 \\
\hline 30 & 55 & 27 & 12,7 \\
\hline 31 & 58 & 29 & 13,7 \\
\hline 32 & 61 & 44 & 20,8 \\
\hline 33 & 64 & 17 & 8,0 \\
\hline 34 & 67 & 13 & 6,1 \\
\hline 35 & 69 & 13 & 6,1 \\
\hline 36 & 71 & 4 & 1,9 \\
\hline 37 & 72 & 5 & 2,4 \\
\hline 38 & 74 & 7 & 3,3 \\
\hline 39 & 76 & 4 & 1,9 \\
\hline 40 & 79 & 4 & 1,9 \\
\hline suma & & 212 & 100,0 \\
\hline
\end{tabular}

Źródło: opracowanie własne. 
Tabela 10.

Wyniki uzyskane przez pedagogów w zakresie skali RK ujęte w przedziałach tenowych

\begin{tabular}{|c|c|c|}
\hline Wynik & Liczba & \% \\
\hline niski & 1 & 0,5 \\
\hline przeciętny & 100 & 47,1 \\
\hline wysoki & 111 & 52,4 \\
\hline suma & 212 & 100,0 \\
\hline
\end{tabular}

Źródło: opracowanie własne.

Analiza danych (tabele 9 i 10) w zakresie skali Rozwiązywanie konfliktów pozwala stwierdzić, że ponad połowa pedagogów $(52,4 \%)$ uzyskała wynik znacząco podwyższony, pozostali $(47,1 \%)$ uzyskali wynik przeciętny. Wynik niski, ale zbliżony do przeciętnego (39T), dotyczył jednego badanego. Nie można więc traktować go jako reprezentatywnego. Najniższy wynik surowy wyniósł 22, najwyższy 40 punktów. Najliczniejszą grupę stanowili pedagodzy z wynikiem surowym w przedziale 30-33 punkty, przeciętna zaś liczba uzyskanych punktów wyniosła 32.

Uzyskane wyniki pozwalają ocenić umiejętność rozwiązywania konfliktów przez badanych pedagogów jako wysoką. Co oznacza, że sprawnie i efektywnie podejmują wyzwania interpersonalne oraz wypracowują konstruktywne oraz społecznie akceptowane zachowania w sytuacjach konfliktowych, tak aby utrzymywać satysfakcjonujące kontakty i relacje międzyosobowe oraz pozytywny wizerunek społeczny.

\section{Wnioski z badań}

Do badania kompetencji interpersonalnych pedagogów szkolnych wykorzystano Kwestionariusz Kompetencji Interpersonalnych ICQ-R. Wybrane narzędzie pozwoliło na określenie pięciu wymiarów kompetencji społecznych, nieodzownych do efektywnego funkcjonowania w relacjach interpersonalnych obejmujących: inicjowanie relacji, asertywne oddziaływanie, ujawnianie siebie, emocjonalne wspieranie i rozwiązywanie konfliktów. W czterech pierwszych wymiarach większość pedagogów osiągnęła wynik 
przeciętny (powyżej 40T), wynik wysoki (powyżej 60T) w tych skalach uzyskał niemal co piąty badany, wynik niski dotyczył nielicznych (IR - 2,8\%, AO - 1,4\%, US - 15,5\%, EW - 1,8\%). Należy podkreślić, że wyniki niskie we wszystkich skalach zbliżały się do średnich. Jeśli chodzi o wymiar piąty - rozwiązywanie konfliktów - zdecydowanie dominował wynik wysoki $(52,4 \%)$, następnie średni $(47,1 \%)$, niski dotyczył zaledwie jednego badanego.

Takie wyniki pozwalają stwierdzić, że badani pedagodzy to osoby, które potrafią inicjować relacje, spotykać się z ludźmi, prowadzić z nimi rozmowy w taki sposób, aby uwzględniać ich potrzeby i pragnienia. W relacjach $\mathrm{z}$ innymi są nastawieni na udzielanie wsparcia emocjonalnego oraz nieunikające eksponowanie siebie, potrafią akcentować swoje zdanie i stanowisko. Wysoki wynik w radzeniu sobie z problemami i konfliktami wskazuje na przekonanie pedagogów o własnej skuteczności, które pozwala im podejmować trud mierzenia się z nimi. W efekcie stają się przywódcami, którzy akcentują swoje stanowisko w ważnych sprawach. Potrafią egzekwować swoje prawa i jasno wyrażać oczekiwania. Częściej biorą sprawy w swoje ręce, niż podporządkowują się innym, ujawniają pragnienia i bronią własnych poglądów. Mówią o swoich oczekiwaniach i trudnościach, nie obawiając się, że może to wywołać sytuację konfliktową czy sporną. W efekcie dają się poznać jako osoby nastawione na udzielanie wsparcia i pomocy swoim podopiecznym, rozumieją ich problemy i z troską pomagają w ich rozwiązaniu.

\section{Podsumowanie - WNiOsKi PRAKTYCZNE}

Badani pedagodzy są wyposażeni w kompetencje społeczne, nieodzowne do efektywnego funkcjonowania $\mathrm{w}$ relacjach interpersonalnych. Posiadane umiejętności determinują styl ich pracy w ramach pomocy psychologiczno-pedagogicznej, rozumianej jako „szczególny rodzaj wzajemnego oddziaływania osoby pomagającej i wspomaganej” (MEN, 2001). Zakres działań pomocowych, w których niezbędne są umiejętności społeczne, jest duży i obejmuje:

- wszystkie podmioty korzystające z pomocy pedagoga: uczniów, wychowanków, rodziców i nauczycieli; pomoc ta polega, najogólniej ujmując, na „wspieraniu w rozwiązywaniu problemów związanych z rozwojem dzieci i młodzieży oraz ich edukacją i wychowaniem” (MEN, 2001, s. 5), 
- proces wspomagania prowadzony przez pedagoga, czyli: diagnozę problemu/problemów, ustalenie programu pomocy zmierzającego do rozwiązania problemu, realizację propozycji naprawczych,

- proces wspomagania realizowany z wykorzystaniem określonych prawem oświatowym form pracy i z uwzględnieniem cech środowiska wychowawczego (szkolnego, rodzinnego, lokalnego), w którym funkcjonują uczniowie.

Umiejętności interpersonalne sprawiają, że współczesny pedagog może być, poprzez działania prowadzone wobec podopiecznych, opiekunem, społecznikiem, mentorem rozjemcą, mediatorem oraz koordynatorem działań opiekuńczo-wychowawczych oraz interwencyjnych w placówce edukacyjnej.

\section{Bibliografia}

Argyle M. (1991). Umiejętności społeczne. W: Argyle M. Psychologia stosunków międzyludzkich. Tłum. W. Domachowski, Warszawa: PWN, s. 66-103. ISBN 8301102268.

Argyle M. (1998). Zdolności społeczne. W: S. Moscovici (red.). Psychologia społeczna w relacji ja - inni. Tłum. M. Cielecki, Warszawa: Wydawnictwa Szkolne i Pedagogiczne, s. 77-104. ISBN 8302069965.

Argyle M. (1999). Psychologia stosunków międzyludzkich. Tłum. W. Domachowski, Warszawa: PWN. ISBN 8301128097.

Argyle M. (2002). Umiejętności społeczne. W: N.J. Mackintosh, A.M. Colman (red.). Zdolności a proces uczenia się. Tłum. J. Gilowicz, Poznań: Wydawnictwo „Zysk i S-ka”. s. 107-142. ISBN 8371508220.

Berk L.E. (1996). Child Development. Boston: Allyn \& Bacon. ISBN 9780205449132.

Bogucka J., Gałecka-Toporek E., Książek W. (2001). Ministerstwo Edukacji Narodowej o pomocy psychologiczno-pedagogicznej [zeszyt oprac. E Gałecka et al. przy współpr. J. Boguckiej et al. pod kier. W. Książka]. MEN. Biuro Administracyjne. MEN o pomocy psychologiczno-pedagogicznej (2001), Warszawa: Wydawnictwo MEN. ISBN 8388035495.

Borkowski J. (2003). Podstawy psychologii społecznej, Warszawa: Dom Wydawniczy „Elipsa”. ISBN 837151543X. 
Dawidowicz M., Klinkosz W. i Śliwak J. (2015). Kwestionariusz Kompetencji Interpersonalnych (ICQ-R). The Interpersonal Competence Questionnaire - D. Burhmestera, M.T. Wittemberga, H.T. Reisa, W. Furmana, Lublin: Katedra Psychologii Społecznej i Psychologii Religii KUL. ISBN 9788365453402.

Jakubowska U. (1996). Wokót pojęcia „kompetencja społeczna” - ujęcie komunikacyjne. Przegląd Psychologiczny 36, s. 29-40. ISSN 0048-5675.

Klinkosz W., Iskra J. i Dawidowicz M. (2017). Kwestionariusz Kompetencji Interpersonalnych. Podręcznik, Gdańsk: Pracownia Testów Psychologicznych i Pedagogicznych. ISBN 9788365453402.

Martowska K. (2012). Psychologiczne uwarunkowania kompetencji społecznych, Warszawa: Wydawnictwo Liberi Libri. ISBN 9788363487034.

Matczak A. (2012). Kwestionariusz Kompetencji Społecznych. Podręcznik. Wydanie II uzupełnione, Warszawa: Pracownia Testów Psychologicznych PTP.

Matuszak A. i Matuszak Z. (2011). Określenie próby i jej liczności w badaniach pedagogicznych. General and Professional Education 2, s. 33-39. Pobrane z: http:// genproedu.com/paper/2011-02/full_033-039.pdf (dostęp 25.02.2019).

Okoń W. (1998). Nowy słownik pedagogiczny, Warszawa: Wydawnictwo Akademickie „Żak”. ISBN 8386770961.

Oleś M. (1998). Asertywność u dzieci w okresie wczesnej adolescencji, Lublin: Towarzystwo Naukowe KUL. ISBN 8387703206.

Sęk H. (2004). Społeczna psychologia kliniczna, Warszawa: PWN. ISBN 8301102411.

Skarżyńska K. (1981). Spostrzeganie ludzi, Warszawa: PWN. ISBN 830102769X.

Smółka P. (2008). Kompetencje społeczne - fenomen skutecznego wywierania wplywu na innych oraz madrego ulegania mu. W: R.E. Biernacka (red.). Niezależni i ulegli - studia o nonkonformizmie, Toruń: Oficyna Naukowa Adam Marszałek, s. 45-54. ISBN 9788376111865.

Smółka P. (2008). Kompetencje społeczne. Metody pomiaru i doskonalenia umiejętności interpersonalnych, Warszawa: Wydawnictwo Wolters Kluwer. ISBN 9788375266337.

Wiatrowski Z. (2005). Podstawy pedagogiki pracy. Bydgoszcz: Wydawnictwo UKW. ISBN 8370965245. 